\title{
Capitalismo naturalista e modo de produção capitalista: crítica ao pensamento de Eugênio Gudin
}

\author{
Maria Angélica Borges ${ }^{1}$ \\ João Ildebrando Bocchi²
}

\section{Resumo:}

Este artigo examina a produção teórica de Eugênio Gudin, que expressa sua nova postura liberal e destaca sua oposição a Roberto Simonsen, à teoria do desenvolvimento econômico da Cepal, ao marxismo e seus seguidores. Gudin reconheceu Karl Marx como o maior inimigo do capitalismo. Ele atribuiu ao pensador alemão a criação do conceito de capitalismo com conotações históricas. Negando radicalmente esse conteúdo e equilibrando a concepção do caráter natural e eterno desse sistema, apresentou o capitalismo como um sistema de produção que se conecta harmonicamente à democracia. Trabalhou com o par economia de mercado e democracia como uma antítese do planejamento e do totalitarismo, estruturando um discurso que enfatiza o plano geral abstrato, desconsiderando uma análise histórica concreta de cada caso específico. Consequentemente, todo aspecto que não se encaixa nesse par é considerado antidemocrático e intervencionista, como uma negação equivalente do ideal humano, às vezes que deve ser evitado ou mesmo destruído.

Palavras-chave: Eugênio Gudin; liberalismo; pensamento conservador.

\section{Naturalist capitalism and capitalist production mode: critical to Eugênio Gudin's thinking}

\begin{abstract}
:
This article examines Eugênio's Gudin theorical production that express his new liberal posture, which highlights his opposition to Roberto Simonsen, Cepal's economic development theory, marxisme and followers. Gudin recognized Karl Marx as the biggest capitalism enemy. He attributed to the thinker the creation of the capitalism concept with historical connotations. Radically denying this content and balancing the conception of the natural and eternal character of this system, he focused the capitalism as a production system which connects itself harmonically with democracy. He worked with the pair economy market and democracy as an antithesis of planning and totalitarism, structuring the discourse that stress the abstract general plan, disregarding a concrete-historical analysis

\footnotetext{
${ }^{1}$ Doutora, professora titular da Pontifícia Universidade Católica de São Paulo (PUC-SP). E-mail: angelica@pucsp.br.

2 Doutor, professor titular Pontifícia Universidade Católica de São Paulo (PUC-SP). Email: jbocchi@pucsp.br.
} 
for each specific case. Consequentely, every aspect that does not fit that pair is considered undemocractic and interventionist, as an equivalent denial of the human ideal, sometimes that should be avoided, or even destroyed.

Key words: Eugênio Gudin; Liberalism; Conservative thinking.

\section{Introdução}

O foco neste estudo é a análise da visão de Eugênio Gudin sobre o capitalismo naturalista e o neoliberalismo. Gudin pode ser considerado o mais importante economista conservador brasileiro, exercendo múltiplos papéis em sua vida centenária. Foi professor de economia, pesquisador e fundador da Fundação Getúlio Vargas do Rio de Janeiro, onde criou o Instituto Brasileiro de Economia (Ibre). Foi ainda ministro da Economia no governo de Café Filho a autor de vários artigos e livros onde se destacava mais como publicista ou divulgador das ideias liberais, do que pelo rigor teórico. A retomada dos escritos de Gudin, mestre dos economistas neoliberais brasileiros, na sua defesa do novo capitalismo ou capitalismo policiado, é necessária por sua atualidade nestes duros momentos de avanço conservador no país.

O século XXI herdou do século XX essa agenda que passou por duas grandes guerras imperialistas, a primeira de 1914-1918 e a segunda de 1939 a 1945, a Grande Depressão de 1930, entre estas guerras, como também as vicissitudes do socialismo real, e o auge e declínio do welfare state keynesiano, conhecido como os 30 gloriosos anos. Também vivenciou a passagem do dólar ouro para o dólar flexível com o fim do acordo Bretton Woods, culminando com a hegemonia da financeirização e o neoliberalismo.

No Brasil, nesse período, a industrialização por substituição de importações transformou uma sociedade rural em urbano-industrial, com um desenvolvimento através da perpetuação da marca colonial e tímidas reformas pelo alto, sem contemplar as transformações clássicas do modo de produção capitalista (BOCCHI, 2018). Colocou um pé no futuro sem tirar o outro do passado. Gudin participou ativamente do debate clássico sobre a industrialização brasileira e o planejamento no Brasil, primeiro com Roberto Simonsen em 1944/45 (MANTEGA, 1984), e depois com Raul Prebisch em 1952/53 (BIELSCHOWSKI, 1995).

\section{I - O capitalismo naturalista e o novo liberalismo}

A primeira seção aborda o conceito de capitalismo naturalista abraçado por Gudin para enfrentar os ataques ao modo de produção 
capitalista. Essa análise se apoia no livro Eugênio Gudin: capitalismo e neoliberalismo (BORGES, 1996). A obra do autor cumpre o papel de ser a guardiã ideológica do sistema econômico e a melhor forma de eternizá-lo é naturalizá-lo. Posicionado na defesa do capitalismo contra os ataques ao seu funcionamento harmonioso apresenta sua visão de mundo. O conceito de capitalismo naturalista será desenhado a partir das palavras do autor, para se entender o que ele pensa a respeito deste conceito e indicar como o sustenta no plano analítico. O discurso dentro da lógica gudiniana revela seu universo categorial, detectando os nódulos que estruturam a sua concepção. O economista carioca mostra os progressos do sistema econômico capitalista, os grandes momentos simbolizados pelas invenções e pela construção da civilização moderna e contemporânea. Saúda a era industrial como a idade de ouro da história da humanidade. Vê os males sociais criados - ou ainda não resolvidos - como algo menor e passível de solução dentro do próprio tecido social. As inequações do capitalismo não o colocam em xeque para o pensador neoliberal, fazem parte de sua evolução natural. Porém, as positividades são ainda maiores que os males do sistema. O homem encontrou a técnica mais racional da atividade produtiva: a economia de mercado. Cabe agora, cada vez mais, aperfeiçoála. Para o autor, há uma lógica imanente de equilíbrio natural vivida pelo capitalismo. Detectado o mecanismo de funcionamento da economia, Gudin enfrenta os profundos abalos que este regime sofreu a partir do início do século XX. Pois, para ele, é só a partir desta data que houve crise no mundo do capital. Mas estas crises não se originaram na economia, entendida como fator. Há crises; estas afetam a economia, porém, nascem do fator político. E a sua gênese foi a I Grande Guerra de 1914-8.

Gudin desconhece o caráter histórico e contraditório do modo de produção capitalista. Mas para onde vai o capital, o conflito vai atrás, como demonstra Beverly J. Silver no seu estudo sobre os movimentos de trabalhadores desde 1870 (SILVER, 2005).

Nos textos percorridos fica clara a responsabilidade que Gudin atribui à Guerra para explicar as crises vividas no século XX. E, cabe frisar mais uma vez, para ele a I Guerra tem a sua origem, fundamentalmente, no fator político. A dimensão desta Guerra para a sua análise é crucial, pois responderá por todas as mazelas ocorridas na primeira metade do século passado. Gudin, com o tema da evolução do capitalismo, indica sua concepção acerca das formas assumidas por este "regime" de produção. Trata-se de uma técnica econômica, natural e racional de gerir a economia. Seu perfil inicial está circunscrito à Europa e, posteriormente, penetrou os demais países dos outros continentes, universalizando-se enquanto sistema de produção. O conceito de capitalismo naturalista usado por Gudin refere-se ao capitalismo do laissez-faire: "O regime econômico que 
no século XIX fez o progresso e a hegemonia da Europa foi o do capitalismo naturalista, que se desenvolveu à sombra da economia liberal e da civilização industrial" (GUDIN, 1938, p. 27). Ele enfatiza:

Graças à indústria e ao capital puderam ser montados no mundo inteiro os laboratórios de pesquisas científicas, com que a humanidade, há quase um século, perscruta os segredos da natureza. Graças ao microscópio, produto da indústria, pode Pasteur realizar a imensa obra de benefício humano que o imortalizou. Graças ao aparelhamento industrial atingimos um "standard" de vida, que faz com que simples operários de hoje tenham mais conforto do que príncipes de outros tempos ou do que Marx e Engels há menos de um século. Não são sequer comparáveis os instrumentos com que a humanidade de hoje se defende do frio, da fome, das intempéries, das infecções e de todas as adversidades que a Natureza pôs no caminho penoso do "homo sapiens". Ninguém de boa-fé negará esses truísmos. (GUDIN, 1936, pp. 27-8)

Em 1943 os mesmos pressupostos reaparecem, ou seja, trata-se da sustentação da tese da evolução natural do capitalismo, da redução do conceito a uma técnica de produção, restrita ao fator econômico, que mantém sua autonomia e se autorregula:

À redução do minério de ferro pelo coque metalúrgico e à máquina a vapor, seguem-se, em rápida sucessão, na primeira metade do século XIX, a navegação a vapor, a locomotiva e as estradas de ferro. A segunda metade desse século é como uma feira de mágicas em que, juntamente com as descobertas de Pasteur, aparecem o motor elétrico, o telefone, as turbinas hidráulicas e a vapor, a lâmpada incandescente, o transporte de energia a distância. $\mathrm{O}$ último decênio do século ainda assiste ao advento do motor de explosão, do veículo automóvel e à infância da aviação. Foi um período de verdadeira exaltação do progresso, cujo ritmo vertiginoso absorvia todas as energias humanas. Era como que uma "fronteira", no sentido de progresso de civilização que a essa palavra dão os americanos. $\mathrm{O}$ século XIX assistiu a um crescimento da população da Europa, superior ao do conjunto dos quatro séculos que o precederam. Mas toda essa população era rapidamente absorvida na febril atividade da "fronteira" na própria Europa ou na América. Não havia tempo para cuidar dos problemas de justiça social nem de uma mais equitativa distribuição da riqueza entre os homens. Tratava-se de conquistar a riqueza e haveria sempre tempo de cuidar, mais tarde, de uma melhor repartição. Foi essa a conjuntura econômica e social que Marx conheceu e profligou na incandescência de seu espírito revoltado. (GUDIN, 1943, pp. 100-1)

Esta citação demonstra como Gudin pensa a evolução do capitalismo. Sua conceituação coincide com a descrição dos inventos deste sistema. Descobrir a civilização industrial é reconhecer a máquina, a 
energia e a produtividade do trabalho. São pressupostos reincidentes em todos os textos analisados. Esta concepção embasa sua postura teórica. É natural para o autor conviver com as injustiças sociais, pois, com esta atividade febril, com este desenvolvimento crescente e constante, não havia tempo para a distribuição da riqueza. Só espíritos "revoltados" é que poderiam querer dar conta desta questão. O mais importante, naquele momento, era conquistar a riqueza, mais tarde se resolveriam os outros problemas, dentro do próprio sistema, é claro. O que temos em Gudin não é a formulação de uma nova teoria econômica, nem o desdobramento de uma das correntes já existentes. Mas sim a alusão à teoria econômica existente na sua vertente tradicional. A visão econômica de Gudin filia-se à posição tradicional, que entende a doutrina econômica, no século XX, como uma tentativa de adaptar os princípios do liberalismo econômico às condições do capitalismo moderno. Seguindo a tradição da escola clássica, os neoliberais acreditam que a vida econômica é regida por uma ordem natural formada a partir das livres decisões individuais e cuja mola mestra é o mecanismo de preços. Entretanto, estes neoliberais, assim como Gudin, defendem o disciplinamento da economia de mercado, não para asfixiá-la, mas para garantir-lhe sobrevivência. Gudin irá usar o termo "policiamento" do sistema. Isto, para ele, não fere os princípios da economia de mercado.

Nesta linha de argumentação, o autor caracteriza o capitalismo naturalista e sua gênese histórica; em seguida, mostra os beneficiários desse sistema e o seu consequente comportamento: "Tão acelerado foi o ritmo de progresso da produção industrial nos países do Ocidente europeu, que eles se acharam, ao cabo de alguns decênios, na contingência de procurar, fora de suas fronteiras, novos escoadouros para essa produção" (GUDIN, 1938, p. 7). Faz parte de sua análise da evolução naturalista do sistema a inexistência do todo homogêneo, pois este ritmo de desenvolvimento acelerado não é compartilhado por todas as nações. Enquanto os países do Ocidente europeu realizavam o capitalismo naturalista, "as demais nações da Europa e de outros continentes não haviam, por sua vez, iniciado a fase industrial" (GUDIN, 1938, p. 7). Porém, esse movimento desigual e combinado, para o autor, faz parte desta dinâmica natural, não rompe o equilíbrio; é, ao contrário, característica da sua lógica, é "a doutrina do livre câmbio, suprimindo barreiras alfandegárias” e abrindo "os escoadouros necessários à produção crescente” (GUDIN, 1938, pp. 7- 8).

O sistema capitalista, com o seu crescimento constante, vai aumentando o volume de sua produção e gerando mais riqueza e capacidade de consumo. Produção e consumo crescentes vão ao encontro da tese de equilíbrio econômico. Este crescimento, por sua vez, impõe 
necessidades técnicas cada vez mais especializadas para o funcionamento da economia. Este equilíbrio econômico natural em Gudin é sustentado pela Lei das Vantagens Comparativas, tese desenvolvida pelos clássicos da economia política desde as escolas smithiana e ricardiana. Para o economista carioca a ligação entre as teses do equilíbrio e da Lei das Vantagens Comparativas torna-se um dos seus pilares: "Quanto mais o grupo de nações industriais vendia seus produtos ao outro grupo, mais lhe compravam produtos agrícolas e matérias-primas e vice-versa" (GUDIN, 1938, p. 8). Neste mundo de equilíbrio havia também obstáculos e o autor não se esquece de mencioná-los, apesar de que, na sua visão, fossem mínimos. Tudo caminhava quase perfeitamente, "apenas perturbado por algumas tendências protecionistas exageradas" (GUDIN, 1938, p. 8). Logo, podemos concluir, juntamente com a análise gudiniana, que o capitalismo naturalista vinha se deslanchando sem nenhum tropeço. Os pequenos desequilíbrios que porventura surgiam eram logo autoajustados pela lógica imanente do sistema de equilíbrio natural:

Se de um lado o progresso industrial de alguns países novos fazia diminuir a importação de determinados artigos, esta redução era logo compensada pelo aumento geral da capacidade de consumo como pela importação dos produtos de novas indústrias criadas pelo gênio da civilização industrial. (GUDIN, 1938, p. 8)

Este paraíso durou, para o nosso economista, até 1914, quando se deflagrou a I Grande Guerra. Para ele, este fato sinaliza o fim de uma época. O mundo capitalista, quanto ao fator econômico, caminhava de forma positiva. Mas, em virtude de acontecimentos decorrentes do fator político, envolvendo paixões e ambições humanas, o equilíbrio econômico foi interrompido. Deixado à mercê de sua própria lógica, o tecido social não conhecia crise. Porém, tal não ocorreu, porque o fator político quebrou a dinâmica do fator econômico. Para o autor, é da lógica interna do fator econômico o equilíbrio natural, assim como a possibilidade de quebra do equilíbrio é exterior a ele. Antes da Guerra, a economia era harmônica e funcionava como uma orquestra executando um concerto. $\mathrm{O}$ "regime capitalista de anteguerra" era "baseado em um largo comércio internacional, em que cada nação tinha a sua função e suas características próprias no concerto geral da Economia Mundial" (GUDIN, 1938, pp. 11-2) No início do século XX, esta harmonia não mais existia, como revelam os fatos a Gudin. O concerto desafinara. E a economia capitalista chegara ao caos. Tal fato coloca perguntas ao autor em questão. Como entender o que está acontecendo? Como o fator político desencadeou tal situação?

Será através da Guerra que Gudin vai explicar a realidade caótica vivida nas primeiras décadas deste século. A Guerra vai gerar novas necessidades e estas alteram a harmonia naturalmente construída. E as 
causas da Guerra surgiram de determinações predominantemente políticas. A cobiça, gerada por paixões políticas e militares, criou o clima para esta catástrofe: "A crise em que o mundo ainda hoje se debate não teve outra origem senão a Guerra que durou quatro anos devastou vidas e riquezas e em que os sacrifícios consentidos pelas nações combatentes atingiram tão flagrante desproporção com os próprios objetivos visados por qualquer delas" (GUDIN, 1936, p. 8). Quem acompanhou "a marcha e a evolução do chamado regime capitalista de 1875 e 1914, até o rompimento da Guerra Mundial", constatou que "o enriquecimento geral prosseguia seu ritmo natural e benéfico, a difusão de capitais se processava com regularidade, as condições de trabalho melhoravam por toda parte, o comércio internacional aumentava todos os anos. E se guerra houve inteiramente gerada pela explosão de paixões e ambições políticas e militares e em que os fatores econômicos menor papel representaram, essa foi a guerra de 1914, que desencadeou sobre o mundo uma das maiores crises econômicas da história" (GUDIN, 1936, p.9).

A economia ia muito bem, mas, por motivos políticos, principalmente, aconteceu a Guerra; isto posto, o caos econômico foi gerado. Alterou-se o equilíbrio, construiu-se um novo cenário. E, diante desta nova realidade, novos atores entram em cena, assumindo papéis importantes, com destaque para os Estados Unidos da América do Norte. Completando suas argumentações Gudin afirma:

Quanto aos Estados Unidos da América do Norte, que já representavam antes da guerra função de relevo na economia mundial, a transformação foi ainda mais profunda. Com um parque industrial que já era capaz de suprir os aliados de munições, canhões, material de guerra e de transporte, o seu enriquecimento de 1914 a 1917 foi vertiginoso, de sorte que, ao término das hostilidades, esse grande país havia-se transformado de país devedor da Europa, que era até 1914, no maior país credor do mundo, sem que entretanto tivesse a experiência e a sabedoria exigidas por essa nova função. Aí está como se processou a desorganização da economia mundial. $\mathrm{O}$ equilíbrio que se havia gradativamente formado até 1914, sob o regime do capitalismo apoiado na economia liberal e que consistia na conjugação harmônica das funções econômicas dos vários países que o constituíam, foi gravemente perturbado pela inversão de valores de suas unidades componentes. As peças do sistema, que d'antes se entrosavam harmonicamente, já não mais se engrenavam, umas às outras. (GUDIN, 1938, pp. 12-3)

E nem todos os países estavam na mesma condição norteamericana, acabada a Guerra; e, pouco a pouco, reorganizada a produção europeia, havia países que não encontravam, de um lado, a quem vender o volume do produto de alimentação e de matérias-primas para cuja exportação se haviam aparelhado, intensificando, segundo Gudin, este 
quadro de desequilíbrio: mesmo porque "não se conformavam em abandonar a organização industrial que haviam edificado durante a guerra" (GUDIN, 1938, pp. 12-3).

Portanto, no plano da história é a negação de uma afirmação, é a impossibilidade de se esgotar no plano restrito do "fator econômico", visto enquanto fator natural, a evolução do capitalismo. Gudin, internamente ao seu próprio discurso, acaba dando-nos os elementos deste processo contraditório. Mesmo afirmando que o conflito bélico está na raiz da explicação da crise econômica, não lhe é possível apagar o quadro de desequilíbrio geral. Mas, para determinarmos melhor o caráter desta discussão, é preciso buscar as outras razões que o autor aponta para indicar o chão social desta crise: "A vida é a evolução e o sistema capitalista, mesmo sem guerra, teria evoluído, como todas as criações humanas" (GUDIN, 1938, p. 15). O capitalismo naturalista evoluiu e tal evolução se processou com vícios. Estes vícios geraram a impossibilidade da eterna harmonia, pois não foram controlados, policiados.

Como vimos, o próprio quadro de desarranjo do sistema leva o autor a ter que explicar os desequilíbrios havidos em todos os níveis. E o fator político, por si só, não conseguiu sustentar sua análise em todas as dimensões, mas havia que concluir o discurso. Para tal, Gudin tem que retornar à realidade econômica; e nela encontra os vícios do sistema. Portanto, os vícios do sistema serão outro elemento que virá somar-se ao seu quadro analítico na tentativa de explicar o ocorrido e salvar o capitalismo. Vejamos como Gudin enlaça esse novo elemento:

A mais elementar lacuna do sistema capitalista, tal como funcionava no primeiro decênio deste século era a ausência de policiamento. A livre disposição pelos bancos de depósitos das economias privadas, sem a fiscalização do estado, a ilimitada liberdade de apelar para a economia privada e para a subscrição de empréstimos de estados, de empresas de negócios de toda espécie, sem que primeiramente o estado certificasse que tais operações tinham de fato o destino e as possibilidades de êxito anunciadas, estavam a exigir, com urgência, o policiamento do sistema. (GUDIN, 1938, p. 15)

O sistema capitalista naturalista ideal guardaria as características já apontadas: livre-concorrência, livre iniciativa, autonomia das liberdades individuais, porém, com um certo policiamento moderador dos apetites, mas não inibidor: "Este simples policiamento, se adotado a tempo, teria poupado ao capitalismo, algumas das mais violentas críticas que lhe foram assacadas" (GUDIN, 1938, pp. 15-6). 


\section{II - O novo liberalismo: o capitalismo policiado}

Como desdobramento conceitual da lógica gudiniana, depois da percepção do significado do capitalismo naturalista, é mister percorrer suas palavras sobre o capitalismo financeiro, pois este passo nos ajudará a completar o seu universo categorial, aproximando-nos mais de seu conceito de novo liberalismo. Vamos a ele:

Acusa-se o capitalismo industrial de ter sido deturpado em suas finalidades pelo capitalismo financeiro; acusa-se o capitalismo de ser o paraíso dos intermediários em detrimento dos produtores e consumidores; diz-se que a civilização industrial fez do homem o escravo da máquina, e ainda agora se atribui ao capitalismo as origens de uma suposta crise de superprodução. (GUDIN, 1936, p. 29)

Gudin não aceita esta ligação e nos clama a raciocinar:

As indústrias precisam de capital, não só de capital de movimento para suas necessidades correntes de compra de matérias-primas, stocks e financiamento de sua produção, como de capital de inversão para o melhoramento de suas instalações, novas máquinas, ampliações, etc. Daí as relações normais e imprescindíveis da indústria com o capital, através dos negociantes de capital, que são os bancos. (GUDIN, 1936, p. 31)

Em oposição às correntes contrárias ao seu ponto de vista, Gudin frisa: que se tem chamado de "capitalismo financeiro" à preponderância, que se diz generalizada, dos bancos ou elemento financeiro sobre o elemento industrial. Segundo esse autor essas opiniões são infundadas e mostram desconhecimento do mecanismo industrial financeiro:

É uma ilusão pensar-se que a direção das indústrias e especialmente da grande indústria pode ser monopolizada pelos industriais, no sentido de técnicos da Indústria. A organização de uma grande empresa industrial não pode prescindir da colaboração dos homens versados e experientes em comércio, em finança e mesmo em matéria legal. $O$ banqueiro não entra na direção das indústrias como um parasita ou um elemento inútil. Ele aparece muitas vezes participando da direção das indústrias como representante de grupos de acionistas que nele confiam para acompanhar e fiscalizar a boa aplicação de seus capitais; outras vezes como hábeis diretores financeiros das empresas, encarregadas de obter em condições favoráveis os capitais necessários ao funcionamento e à expansão da indústria. (GUDIN, 1936, pp. 31-2)

Apresentando outra opinião diferente do que "se diz" - pois Gudin não localiza os seus opositores nesta questão; coloca-os na forma indeterminada -, recusa a visão de que o banqueiro e as pessoas indicadas 
por ele para assumirem postos de comando nas empresas sejam uma ingerência do capital financeiro sobre o capital industrial:

Os que se insurgem contra a colaboração, que indústria, esqueceram-se de que toda a grande e média Indústria não é propriedade de um, dois ou três indivíduos e sim de uma coletividade de acionistas. Estes acionistas são pessoas que dispõem de economias e de reservas recolhidas a estabelecimentos bancários de sua confiança ou preferência. É pelo intermédio forçoso das organizações bancárias que se faz a subscrição de capital de que precisam as indústrias. (GUDIN, 1936, pp. 31-2)

Em função do dito acima podemos constatar que o autor não vê como sendo problemático o relacionamento entre o capital industrial e o financeiro. Um socorre o outro, segundo a sua visão analítica: "Colaboração não quer dizer preponderância, como bem assinala Sombart" (GUDIN, 1936, p. 32).

E, a partir das palavras de Sombart, explicita ainda mais a sua concepção: "Tem-se pretendido que as relações entre bancos e empresas industriais importam na sujeição destas àquelas e fala-se a este propósito de uma 'bancarização' da indústria, de uma preponderância do capital financeiro" (GUDIN, 1936, p. 32). E continua:

Este modo de ver é falso. Poder-se-ia do mesmo modo falar do domínio da indústria sobre os bancos. A situação varia de um caso para o outro. Ora é o banco que representa o papel dominante, ora é a empresa industrial: isto depende das razões objetivas e pessoais que não são as mesmas em todos os casos. Mas é a fase de desenvolvimento da economia que exerce a influência decisiva. (GUDIN, 1936, pp. 32-3)

Depois de desenhar um quadro com as palavras de Sombart, pincela seu próprio diagnóstico:

Nada mais lógico e mesmo mais moral do que o banqueiro, que aconselha a seus clientes e amigos a inverter seus capitais em uma indústria, vir sentar-se no conselho de direção dos negócios dessa indústria, trazendo o benefício de sua colaboração, de seu esforço e de sua experiência na direção financeira. Quando essa colaboração é desnecessária, quando o industrial dispõe de todo o capital de que precisa e tem os conhecimentos, a experiência e as relações necessárias para a direção financeira de seu negócio, ele não vai buscar a colaboração de banqueiro algum. Ao contrário, nesses casos são os bancos que disputam a preferência do industrial para seus depósitos e descontos. (GUDIN, 1936, p. 33)

Gudin enxerga naturalmente a colaboração mútua entre os capitais; no seu olhar, tudo se passa como sendo uma mera divisão de funções; não há ingerência e sim colaboração. A evolução do capitalismo naturalista gerou o capitalismo financeiro que, dentro das funções descritas até agora, 
não apresenta problema algum. Nota-se que, em toda a sua explanação sobre o capitalismo financeiro, em nenhum momento ele mencionou a "especulação financeira". Sendo que, anteriormente, quando analisava o capitalismo naturalista, afirmara que os vícios que levaram ao desequilíbrio do regime tinham como causas o monopólio e a especulação financeira.

Neste sentido, parece relevante frisar que, na sua discussão específica sobre o capitalismo financeiro, não há menção aos vícios do sistema, somente há indicações positivas entre indústrias e finanças. Logo, especulação financeira e monopólio não são, para o autor, momentos de sua análise do capitalismo financeiro. Sua fala restringe-se à colaboração dos capitais. Cabe então alertar para a indicação de Gudin, na sua própria análise, de que o capitalismo financeiro é visto no seu ideário como um elemento técnico do funcionamento do capitalismo. Não lhe é atribuída nenhuma relação com o conjunto do sistema, com a totalidade em processo, com o movimento do ser e ir sendo capitalismo.

Outro ponto a ser tratado aqui, relacionado a esta discussão, é a análise que o autor faz dos "intermediários" e sua posição dentro do sistema. De saída, ele não aceita as críticas aos intermediários: "A acusação contra o sistema capitalista de ter criado intermediários parasitas é rematada tolice" (GUDIN, 1936, p. 35). A base do capitalismo é a livreconcorrência; isto se põe como condição sine qua non do autoajuste e, estando garantida esta condição, não há o que desarranje o sistema. Portanto, o intermediário não causa males. $\mathrm{O}$ mal só aparece com o fim da livre-concorrência.

Quando desaparece a livre-concorrência e se formam os "trustes" ou os "corners" com o objetivo de monopolizar um determinado produto ou forçar os seus preços a nível artificialmente elevado, aí sim é que o Poder Público, por suas leis, tem o direito e o dever de intervir para restabelecer, em sua plenitude, o funcionamento do regime capitalista, que é o da livre-concorrência. (GUDIN, 1936, p. 35)

Os papéis, no sistema capitalista, estão bem definidos; assim, garantindo-se as condições naturais do funcionamento do mercado não há crise; pelo menos da economia natural capitalista:

$\mathrm{O}$ industrial e o agricultor não são, em princípio e em regra, negociantes. Seu interesse é o de vender toda sua produção o mais depressa possível e receber o dinheiro para fabricar e produzir mais. O grande comércio em grosso é o comprador natural da produção das fábricas. (GUDIN, 1936, p. 35)

O comerciante é um elemento entre a produção e o mercado:

É o grande vendedor que constantemente ausculta o mercado, conhece suas necessidades, sabe o que se deve fabricar para vender e sabe também a quem vender e a quem dar crédito. Ele 
dirige pelo país inteiro a sua rede de distribuidores que são os seus agentes em outras cidades ou os seus viajantes. (GUDIN, 1936, p. 35)

Em suma, é um membro da divisão do trabalho: "É uma tarefa estranha e diferente da tarefa do industrial. É uma organização distribuidora indispensável e cujo negócio envolve riscos não pequenos" (GUDIN, 1936, pp. 35-6). Como vimos, os intermediários, assim como o capitalismo financeiro, são suportes técnicos do capitalismo naturalista: "Nenhum fundamento tem portanto a acusação ao sistema capitalista, por seus supostos vícios da organização intermediária do comércio, que aliás nada tem de peculiar ao capitalismo e que sempre existiu antes dele" (GUDIN, 1936, pp. 36-7). Mais uma vez, para o autor, fica descartada qualquer possibilidade de não-funcionamento automático do capitalismo naturalista. As engrenagens encaixam-se perfeitamente bem. As funções são explícitas nesse engajamento perfeito e natural. Não há possibilidade de crise econômica, no sentido de que a economia capitalista aparece para o autor como natural e racional.

Será dentro deste mesmo clima - em que acabamos de analisar o papel do capitalismo financeiro - que Gudin abordará a relação entre maquinaria, superprodução e desemprego. Ou seja, estas relações aparecem de forma mecânica e desvinculada do todo social. A maquinaria é entendida dentro do seu próprio universo, simplesmente como técnica. $\mathrm{E}$ a superprodução, como o desemprego, não guardam com esta nenhum parentesco. Estas relações são abordadas tendo como pressuposto que o sistema capitalista realiza o pleno emprego dos fatores de produção; consequentemente, a superprodução e o desemprego são fenômenos para além da esfera econômica. Comecemos pela superprodução e vejamos a posição do autor a respeito deste fenômeno: "Dentre os múltiplos diagnósticos das origens da crise, cujos efeitos ainda perduram, nenhum adquiriu tão largos foros de verdade, como o de uma suposta superprodução decorrente do excesso de aparelhamento mecânico e industrial, produto do regime capitalista" (GUDIN, 1936, p. 45).

Todavia, no plano econômico, falar em superprodução é referir-se a uma "suposta superprodução". Mas, continuaremos dando voz ao autor: "Verificado o incontestável desequilíbrio entre a capacidade de produção e o consumo real, conclui-se, por um raciocínio apriorístico, que o mal reside no excesso de produção. É uma simples conclusão de sentimento e de palpite, que não resiste entretanto a qualquer análise" (GUDIN, 1936, p. 45). Negando esta análise, que é reduzida ao "sentimentalismo de palpiteiros", apresenta a sua: "O estudo, já tantas vezes feito, do ritmo da produção nos últimos 30 anos, demonstra claramente, para cada espécie dos principais produtos, que esse ritmo manteve-se quase constante e sem 
qualquer aceleração nos anos que precederam a eclosão da crise” (GUDIN, 1936, p. 45).

$\mathrm{Na}$ evolução do capitalismo naturalista, nenhum país atingiu ainda o pleno desenvolvimento. Estamos diante de um mundo em desenvolvimento, que sofreu com a Guerra (fator político) um enorme abalo. A produção caminhava, paulatinamente, de forma satisfatória para os padrões gudinianos. Com a perda da paz política, perdeu-se o equilíbrio econômico. Gudin reconhece na Guerra a origem da crise e aproveita esta "catástrofe" para analisar o seu momento histórico: "E se alguma vantagem indireta nos adveio dessas catástrofes, foi a de forçar-nos a uma parada para analisar seriamente a situação econômica do mundo e determinar as coordenadas reais de nossa posição nesta etapa de nossa evolução" (GUDIN, 1936, pp. 46-7). Favorável a um ajuste de contas com o momento vivido pela humanidade durante a I Grande Guerra, assim como com o posterior, a crise de 1929, traça as seguintes coordenadas: "A crise de 1929, como todas as suas congêneres, nasceu do profundo desequilíbrio entre as economias das várias nações e, dentro de cada nação, entre seus vários fatores de produção e consumo" (GUDIN, 1936, p. 47).

O capitalismo naturalista criou um "regime de estreita interdependência econômica das nações, a que o progresso da Civilização Industrial já havia conduzido a humanidade, para seu grande benefício" (GUDIN, 1936, p. 47). Com a Guerra, gerou-se um colapso econômico e a "repercussão dos formidáveis abalos econômicos sofridos por essas grandes nações se fez sentir com grande intensidade sobre o resto do mundo" (GUDIN, 1936, p. 47). Gudin se refere a outros fenômenos da história social que, segundo seu parecer, reforçam sua tese:

Já foi, a esse propósito, muitas vezes contada a história da repercussão da guerra russo-japonesa sobre a economia dos Estados Unidos. Os Russos que eram os grandes compradores de chá da Índia, deixaram, por falta de disponibilidade no exterior, de importar esse produto, de sorte que a Índia, grande compradora da indústria inglesa de tecidos, não vendendo o seu chá, não tinha recursos para continuar a importação dos tecidos ingleses. (GUDIN, 1936, pp. 4-87)

Como consequência, a

Inglaterra, tendo assim sofrido um profundo desfalque em sua exportação de tecidos, passou a não comprar o algodão dos Americanos, de sorte que a população agrícola dos Estados Unidos ficou sem recursos para adquirir, como normalmente o fazia, os produtos da Indústria de seu país, causando o desequilíbrio e a forte crise econômica dos Estados Unidos de 1905. Multiplica-se isso por cem e ter-se-á uma noção do grau de desequilíbrio econômico causado pela Grande Guerra (GUDIN, 1936, p. 48). 
No final da citação, ficou nítido onde se queria chegar - no coroamento de sua tese -, que a crise teria sua origem no fator político. Justificando o sistema e jogando a culpa nos desatinos humanos, na fúria desenfreada, resta-lhe concluir que o capitalismo só não faz milagres. $\mathrm{O}$ de curar os desatinos humanos. "E, tanto quanto alcançaram meus parcos conhecimentos, ainda não apareceu outro sistema que se proponha a realizar esse milagre" (GUDIN, 1936, p. 43). Outro fenômeno, visto por Gudin, que ponderaremos, é sua abordagem da relação entre maquinaria e desemprego. Esta relação também será averiguada tendo como pressuposto que o sistema capitalista realiza uma lógica de equilíbrio, como dissemos no começo desta discussão. Em suas palavras ficará explícito este seu modo de pensar: "Diante da expansão e do progresso da civilização industrial nos últimos 150 anos, se fosse certa a teoria de que a máquina acarreta o desemprego, a metade dos trabalhadores do mundo civilizado já estaria hoje desempregada. E até 1918 não havia praticamente desemprego, nas grandes nações industriais" (GUDIN, 1936, p. 39).

Ligado ao cenário da I Grande Guerra, o desemprego é citado como seu desdobramento: "Como explicar que o mundo ocidental que há mais de um século vem sendo mecanizado, só viesse a conhecer o problema do desemprego depois do formidável desequilíbrio econômico criado pelo fator político que foi a guerra? Por quê?" (GUDIN, 1936, p. 493). No caráter de sua resposta vemos também o pressuposto de sua reflexão:

\section{Em primeiro lugar, porque a máquina precisa de operários para ser fabricada. Mas essa fabricação não exige somente operários; exige aço, ferro, peças manufaturadas que têm de ser adquiridas da grande indústria de ferro e aço, que assim também passa a precisar de operários. As estradas de ferro que transportam tudo isso também precisam de mão-de-obra. Mas a máquina não anda sozinha. Ela precisa de combustível ou de energia elétrica e de lubrificação, donde a necessidade de aumentar o número de operários para a extração e transporte do combustível ou para a produção de energia e de lubrificantes. (GUDIN, 1936, p. 39)}

Ao iniciar a formulação da sua resposta, Gudin indica, com relação ao "fator econômico", haver uma engrenagem natural em que a produção cria a sua própria demanda e o ritmo natural do desenvolvimento gera novos empregos, novas oportunidades. No plano da economia inexiste maquinaria em desenvolvimento acompanhada de desemprego: "A máquina, reduzindo o custo da produção, aumenta o consumo do artigo fabricado, de sorte que o aumento de operários que a introdução da máquina passa a exigir, fica multiplicado por um coeficiente de expansão" (GUDIN, 1936, p. 40). Como estamos vendo, não há razão na evolução do capitalismo naturalista, para que a máquina gere desemprego. Por enquanto, o autor só vê progressos na mecanização do mundo, a evolução 
natural do capitalismo é a evolução da sociedade: "Não há comparação entre o número do trabalhadores que perderam o emprego de guiar carroças ou diligências e o número dos que hoje trabalham na indústria de automóveis e na condução e manutenção desses veículos" (GUDIN, 1936, p. 40). Vendo a sociedade estruturada por fatores - o fator econômico, o fator político e assim por diante -, Gudin preserva cada fator dentro da sua própria autonomia. Sendo assim, segundo ele, o fator econômico ia muito bem, não havia crise no sistema; logo, foi o fator político o responsável pelo desemprego. Este fator tomou corpo na I Guerra Mundial, sendo esta o porquê de tudo:

Tal era o ritmo da economia humana sob o regime capitalista, que só depois da Guerra veio conhecer o problema do desemprego. Mas mesmo quando esse problema chegou, como consequência de uma das maiores crises porque a humanidade tem passado, ela já estava bastante enriquecida para poder amparar os desempregados, que em crises semelhantes, anteriores ao sistema capitalista, eram condenados a morrer de fome e de frio pelas estradas à fora. (GUDIN, 1936, p. 40)

O fator político gerou a Guerra, o desemprego, o desequilíbrio econômico. O fator econômico ia muito bem, em ritmo de crescimento acelerado. Porém, foi interrompido pelo fator político, que suspendeu o seu curso natural. Mas, mesmo assim, o fator econômico ajudou a salvar a crise; pois com o que tinha acumulado anteriormente, abrigou, confortou os desamparados pelo fator político (a I Grande Guerra). No clima desta discussão, Gudin enlaça a problemática da maquinaria com a crítica que é feita ao capitalismo, de ter escravizado o homem moderno à civilização industrial. E, também, enfatiza o que já vem afirmando com relação às positividades da relação capitalismo e mecanização do mundo:

Dentre as críticas de que é alvo o sistema capitalista ou mais propriamente a civilização industrial, nenhuma oferece tanto interesse de análise como essa que o acusa de ter escravizado o homem a seu regime de trabalho mecanizado. Espíritos dos melhores, na essência como na intenção, têm endossado a teoria de que a civilização industrial destruiu os laços que ligavam o produtor ao objeto produzido, o cunho de personalidade que o homem emprestava ao produto de seu trabalho, para transformar esse trabalho em uma tarefa impessoal mecanizada, especializada e monótona. (GUDIN, 1936, p. 41)

Enfrentando a problemática do estranhamento na relação trabalho assalariado e capital, o economista procura desmentir a possibilidade de o produto do trabalho voltar-se contra o trabalhador, criador desse produto. Nega a possibilidade da alienação do trabalho, enquanto momento da exteriorização da subjetividade do trabalhador na objetivação do objeto, e do objeto tornando-se, ao fim e ao cabo do processo, estranho ao próprio trabalhador. Como, da mesma maneira, não aceita que a repetitividade, a 
subsunção do trabalhador ao meio de trabalho também gere tal estranhamento.

Reconhece que esta discussão é da maior relevância para a sociedade e passeia por alguns teóricos, escolhidos a dedo, para driblar o fenômeno:

Essa teoria, tão sedutora para todos os bons espíritos, tem sido defendida por pensadores cujo mérito intelectual merece o maior acatamento. Gina Lombroso dedicou-lhe um livro inteiro, intitulado "Retour à la Prospérité" e ainda há poucos meses o ilustre biologista franco-americano Alexis Carrel, em seu grande livro "L'homme cet inconnu" desenvolveu com ardor a mesma tese. Profligam a forma de trabalho dos grandes centros industriais e clamam pela volta a um regime de artesanato individual, de satisfação de cada um no acabamento do produto de sua execução, de tarefa sem hora marcada e sem quantidade pré-determinada, fora do ambiente mecanizado da grande indústria e das colmeias humanas. (GUDIN, 1936, pp. 41-2).

Escolhendo a posição romântica da discussão do estranhamento do trabalho para se opor, reage e se manifesta contra essa visão idílica do trabalho humano:

Não há quem negue a esse belo ideal assim expresso, o grande fundo de bondade e de poesia humana que ele encerra, mas infelizmente essa tese, nas atuais condições da humanidade, nada mais é do que um belo anseio, uma linda poesia, aplicável talvez ao trabalho artístico, mas inteiramente inadaptável ao regime de grande produção a baixo preço de custo, indispensável à satisfação das necessidades mais urgentes do homem civilizado. Essa concepção de trabalho-prazer, atrativo, interessante e ameno, é do reino dos sonhos. (GUDIN, 1936, p. 42)

Como dissemos, privilegiando este aspecto lúdico da discussão e ressaltando-o à guisa de contraponto, enfatiza o ângulo pelo qual acha que a questão deva ser enxergada. Este ângulo é o da racionalidade do capital na figura do industrial, mas do industrial lúcido:

Preliminarmente, é preciso não esquecer que o regime de produção em larga escala e baixo preço de custo não é o produto de uma fantasia de capitalistas em delírio de grandezas. O regime de produção intensiva que praticamos corresponde a uma premente necessidade social de produzir, a baixo preço, os objetos necessários à existência do homem civilizado, para que sua aquisição de torne cada vez mais acessível ao poder de compra de todas classes sociais. (GUDIN, 1936, p. 42)

Não há possibilidade de ser diferente, pois assim já é a melhor possível; e, não sendo lúdica a relação capital e trabalho - pois a realidade não a comporta -, não existe nenhuma outra crítica plausível às relações de 
produção capitalistas. Para ele, o produto do trabalho não se volta contra o trabalhador, de nenhuma forma; ao contrário, está a seu favor: "Artigos que há um século só os ricos podiam adquirir, são hoje de uso corrente nas classes operárias e é graças a esse regime de produção que, (...) o operário de hoje pode gozar de um 'standard' de vida bem superior ao que, há um século, era o privilégio dos afortunados" (GUDIN, 1936, p. 42). É possível melhorar, mas dentro da evolução natural do sistema capitalista, como podemos observar olhando a história com os óculos gudinianos:

Não precisamos reduzir o homem à condição de servo de gleba e da máquina. As condições de trabalho humano no regime da Civilização Industrial têm progredido consideravelmente nos últimos cem anos, tanto em facilidade como em duração. E os progressos da técnica revertem em imediato benefício social, como diz Henry Ford e como concluiu o recente e notável trabalho da "Brookings Institution", de sorte que a cada nova etapa de progresso, se possa aumentar o salário do operário e baixar o preço do produto fabricado, o que corresponde a aumentar o poder aquisitivo da sociedade e portanto enriquecêla. (GUDIN, 1936, p. 44)

Para o autor, assim como é natural a evolução mecânica do sistema, natural também é a evolução da condição do trabalhador no sistema.

Outro ponto importante a ser discutido é a visão de Gudin sobre a depressão. Vamos verificar como ele a dimensionou dentro do capitalismo, assim como estabeleceu sua relação com a Guerra e o novo liberalismo. Esses pontos são debatidos em nossa análise do autor, que vê nestes fenômenos o desequilíbrio dentro do equilíbrio. A depressão - gerada externamente ao fator econômico pelo fator político - acarretou uma desordem na estrutura econômica. O equilíbrio natural do sistema capitalista sofreu um revés, houve uma mudança da liderança britânica para a americana. Neste novo contexto, urge discutir e resolver os problemas gerados. Como veremos, para Gudin, o caminho que soluciona este drama mundial é o novo liberalismo.

Agora, cabe mostrar qual a sua definição acerca deste fenômeno: "A grande depressão não foi um simples fenômeno cíclico como os do século XIX e sim a consequência de uma grave ruptura do equilíbrio econômico nacional, e internacional das principais nações do mundo" (GUDIN, 1943, p. 107). Gudin aponta para um desequilíbrio representado pela grande depressão. Para entendermos como esse desequilíbrio foi constituído, é necessário, antes, verificar o que ele pensa de equilíbrio: "Não é preciso ser matemático para compreender que em sociologia como em economia, a noção de equilíbrio é dinâmica. Organismos vivos que são, as sociedades e as economias em progresso, o seu equilíbrio só pode ser dinâmico e não estático" (GUDIN, 1943, p. 99) Explicando melhor estes conceitos, pondera: "Quando falamos em desequilíbrio da economia do mundo 
moderno, o conceito tem forçosamente de ser relativo; queremos dizer que 'em relação a outros períodos da história contemporânea' a economia do mundo atual apresenta uma série de desarmonias e distorções de seus elementos componentes, uns em relação aos outros" (GUDIN, 1943, p. 99) No dizer de Gudin, o desequilíbrio dentro da economia é um momento dentro do equilíbrio. Portanto, algo relativo. O desequilíbrio, quando ocorre, revela algumas distorções que podem ser corrigidas.

A Grande Depressão aconteceu como resultado da I Grande Guerra que, por sua vez, foi detonada por motivos predominantemente políticos. E esta lógica reaparece na II Grande Guerra. Analisemos mais de perto: "Na Alemanha, uma das maiores unidades do sistema econômico mundial, a situação de caos político e social da República de Weimar conduziu à catástrofe de uma das maiores inflações a que o mundo já assistiu." (GUDIN, 1943a, p. 104) Está nas suas palavras a tese de que o caos social e político gera inflação. "Naquele país, onde a guerra terminou com o equilíbrio econômico local e internacional, seguiu-se após breves interregnos de desenvolvimento a Grande Depressão, como consequência deste estado de coisas anteriores." (GUDIN, 1943a, p. 104) Após um curto tempo "a forte corrente de capitais americanos deram a ilusão de uma volta ao equilíbrio, logo desfeita pelo alastramento, em 1930, da grande depressão vinda do exterior. Seguiu-se Hitler, o isolamento econômico, a economia de guerra" (GUDIN: 1943a, p. 104)

Esta espiral de caos social e político engoliu todas as nações do mundo contemporâneo: "A Inglaterra, que com tanta sabedoria empunhava antes da guerra a batuta da orquestra econômica internacional, teve de passar o comando aos Estados Unidos. Esta mudança de regente, que se deveria fatalmente verificar com o tempo, através de uma lenta evolução, foi efetuada de modo abrupto" (GUDIN, 1943, p.106) A Guerra mudou as lideranças e o curso natural dos seus movimentos de alternância, levando a atos desaconselháveis no plano da economia: "A própria Inglaterra, esquecendo os conselhos de Ricardo enveredou por uma política de deflação monetária firmada em 1925 com a volta da libra esterlina à antiga paridade-ouro (GUDIN, 1943, p. 104). Diz:

Essa absurda deflação (sempre combatida por Keynes) custoulhe uma grande depressão da atividade econômica, baixa de preços e cifras alarmantes de desemprego. Ainda hoje é o unemployment o pesadelo da Inglaterra. Só em 1937, graças aos preços muito baixos a que haviam caído os produtos de alimentação e matérias-primas de sua importação, conseguia ela dar novo impulso às suas indústrias e à sua economia, mas aí ela já começava também a preparar-se para a nova guerra. (GUDIN, 1943, p. 104)

A Guerra causou um estado de desequilíbrio na entrada do nosso século. Houve desestruturação mundial geral. Neste livro intitulado Para 
um mundo melhor, onde o autor analisa os problemas que virão com o término da Guerra de 1939-45, ele retoma teses já indicadas nos textos de 1936 a 1938. Uma delas é sua análise sobre o novo papel dos Estados Unidos: "O maior elemento de desequilíbrio da economia mundial teve origem na rápida mutação da situação econômica dos Estados Unidos da América do Norte, que de país devedor e importador de capitais que era antes da guerra, passara a ser a maior nação credora do mundo" (GUDIN, 1943, p. 105). Mas: "Uma nação só pode pagar a outra nação em mercadorias e serviços, ainda que a mercadoria seja, em último recurso, o ouro, que aliás já estava quase todo nos Estados Unidos. Como pagar-se a nação credora, que exporta mais do que importa?" (GUDIN, 1943, p. 106).

Diante deste contexto o caos está instaurado. A velha líder, a Inglaterra, enfiada numa depressão (em função da I Grande Guerra), não podia continuar sendo a timoneira do barco da história mundial. Entretanto, o novo líder padecia, por inexperiência, de condições efetivas para lograr um grande sucesso. Indo a fundo neste ponto, evidenciando a posição já conhecida do autor, seguimos os seus passos para explicá-lo ainda mais. A fim de compreender melhor esses fenômenos, ele lança o seu olhar para o mundo econômico de antes da I Guerra e, assim, fecha a sua análise com relação a este ponto, pois nesse período a liderança é inglesa. E Gudin une a experiência inglesa com o mundo de equilíbrio visualizado no século XIX. Liderança britânica e equilíbrio econômico constituem um dos nódulos de sua análise da evolução da civilização industrial: "Este país comprava ao resto do mundo perto de 300 milhões de libras por ano mais do que vendia e eram esses 300 milhões de libras de mercadorias que permitiam às outras nações satisfazer o pagamento de seus empréstimos à Inglaterra" (GUDIN, 1943, p. 106).

O comportamento norte-americano, para o nosso economista, difere do inglês. Essa mudança do eixo econômico internacional acentuou os desequilíbrios de pós-I Guerra. E, ainda mais, os Estados Unidos eram - dentre as demais nações do mundo europeu - um país muito jovem, sem experiência e condições de desempenhar tão bem seu novo papel, como a Inglaterra desempenhara no passado:

A estrutura monetária e bancária dos Estados Unidos não tinha ainda adquirido a solidez desejável. O Sistema de Reserva Federal havia sido criado um ano apenas antes da guerra de 1914; não adquirira ainda a experiência necessária para controlar um sistema bancário muito vulnerável não só pela enorme multiplicidade de bancos como por um mercado monetário especialmente acessível à especulação bolsista, como a que estourou em outubro de 1929, marcando o início da maior depressão econômica dos tempos modernos. (GUDIN, 1943, pp. 106-7) 
Eis sua linha lógica: a Guerra de 1914 gerou instabilidade econômica, mudou as lideranças mundiais, colocou a nação norteamericana - sem experiência e condições favoráveis - no topo do mundo. Essa imaturidade levou-nos à Grande Depressão. Nada adveio da economia propriamente dita. São as circunstâncias políticas que interferem na economia e geram a desestabilização. Gudin reduz o fenômeno de 1929 às condições da Guerra de 1914.

$\mathrm{Na}$ sequência dentro da trilha dos seus argumentos, analisemos como ele enfrenta o mundo do final da primeira metade do século $\mathrm{XX}$, principalmente com relação ao planejamento econômico, que suscitou um posicionamento firme tanto de neoliberais como de socialistas:

A economia planificada é um produto genético do desequilíbrio econômico dos últimos 25 anos, que acabamos de descrever. Ela se origina da incompreensão desse desequilíbrio. Ela não percebe que o problema consiste essencialmente em encontrar novas posições de equilíbrio e que uma vez atingido esse equilíbrio, a economia planificada torna-se, na melhor das hipóteses inútil. (GUDIN, 1943, p. 108)

Excetuando o período da Guerra e o ajuste à nova situação, a economia planificada não tem nenhum papel a cumprir; ao contrário, atrapalha: "Como sistema geral de economia de paz (...) ela não resiste à análise" (GUDIN, 1943, p. 109). E o que resiste? Para Gudin é o novo conceito do liberalismo. O liberalismo se põe como o único anteparo contra todas as formas de organização social que, no fundo, destroem o ideal humano de liberdade e democracia. Vejamos como ele entende o entrelaçamento destas questões:

Fórmulas corporativas, fórmulas sindicalistas, sistemas fascistas ou comunistas, nada mais são do que coletivismo com tabuletas diversas. Não se trata aqui de distinguir entre umas e outras modalidades de coletivismo. O debate é entre o liberalismo e o conjunto dos coletivismos. Os liberais procuram conservar e aperfeiçoar a ordem econômica que os coletivistas desejam destruir. (GUDIN, 1943, pp. 171-2)

Reduz diferentes ideologias ao mesmo denominador comum, desconhecendo as formas particulares de respostas que significam na história da humanidade, qualificando, simplesmente, de anticapitalistas, não importando qual proposta alternativa representam à sociedade; sendo suficiente apenas reafirmar os ideais do liberalismo como a melhor forma de sociedade.

Gudin contrapõe uma visão à outra, tendo como único recurso o apelo à fé para persuasão de que o liberalismo é a forma de redenção da humanidade. Afirma sua superioridade, não a demonstra. Indica, mas não analisa. É a fé cega no capitalismo. Como se este sistema, por si só, resolvesse todos os problemas da humanidade, bastando apenas 
mencioná-lo. Liberalismo versus coletivismo, esta é a fórmula redutora a que Gudin chega, como já vimos anteriormente. Constrói um amálgama de filosofias diferentes e antitéticas, somente mencionando-as sem uma análise efetiva do significado de cada uma delas. Reconhece neste mosaico somente um ponto em comum: o totalitarismo, como sinônimo de coletivismo. Não nos oferece nada mais que esta fórmula redutora. E, contra todas essas tentativas de respostas para organizar a sociedade antiliberais -, ele evoca os adeptos do liberalismo. É o novo liberalismo, que vai superar todos os problemas encontrados no início do século, visto que engloba as positividades do liberalismo e corrige seus defeitos. Gudin nos oferece roupagem nova para velhos ideais. Esses ideais, que continuam válidos no seu entender, só precisam ser aperfeiçoados. A essência é boa e deve ser mantida. Renová-la não significa negá-la, ao contrário, é eternizá-la como proposta, como defesa da liberdade e da democracia:

O novo conceito de liberalismo a que aqui nos referimos não é o liberalismo do laissez-faire de Herbert Spencer e de Stuart Mill; não é o liberalismo que assegura a liberdade de uns homens explorarem o trabalho de outros homens, não é o liberalismo de licença que sanciona os abusos praticados por um capitalismo sem polícia. (GUDIN, 1943, p. 174)

O velho liberalismo já cumpriu o seu papel, foi eficiente na sua trajetória, porém, criou vícios que o novo liberalismo terá que dar conta. $\mathrm{O}$ mundo estava economicamente perfeito no século XIX. Mas as ambições, as paixões humanas, os vícios, enfim, que tais sentimentos geram, determinaram o início da Guerra. Como consequência, conhecemos o desequilíbrio mundial, a mudança de liderança da tradicional Inglaterra para os inexperientes Estados Unidos; a Grande Depressão e o nascimento das filosofias totalitárias.

É necessário reagir a tudo isto, reordenar o mundo retomando o que havia de melhor no passado: o liberalismo. E vaciná-lo contra os males que poderiam se repetir e gerar novos desequilíbrios. O velho liberalismo vacinado transforma-se no novo liberalismo.

O novo liberalismo supera o velho liberalismo, sendo que, para Gudin, os teóricos do velho liberalismo concebiam a sociedade como um todo social, sendo esse inclusive um ponto comum com as ideias marxistas. O seu novo modo de conceituar o liberalismo supera esses limites do passado sem precisar superar o liberalismo.

Marx, a seu tempo, já enfrentou esse debate e as ilusões geradas na dualidade monopólio x livre-concorrência; e, a partir da discussão sobre o método metafísico utilizado por Proudhon na sua obra Filosofia da miséria, colocou esta controvérsia com os pés enterrados na dialética em sua vertente materialista: "Todos sabemos que a concorrência foi 
engendrada pelo monopólio feudal. Assim, pois, inicialmente, a concorrência foi o contrário do monopólio, e não o monopólio o contrário da concorrência. Portanto, o monopólio moderno não é uma simples antítese, mas pelo contrário é a verdadeira síntese" (MARX, 1977, p. 143). Assim:

$\mathrm{Na}$ vida prática encontramos não apenas a concorrência, o monopólio e o antagonismo entre uma e outra, mas também a sua síntese, que não é uma fórmula, mas um movimento. $\mathrm{O}$ monopólio engendra a concorrência, a concorrência engendra o monopólio. Os monopolistas competem entre si, os competidores passam a ser monopolistas. Se os monopolistas restringem a concorrência entre eles, por meio de associações parciais, acentua-se a concorrência entre os operários; e quanto mais cresce a massa de proletários, com relação aos monopolistas de uma nação, mais desenfreada é a concorrência entre os monopolistas de diferentes nações. A síntese consiste em que o monopólio não pode manter-se se não se entregar, continuamente, à luta da concorrência. (MARX, 1977, p. 143)

Quando olhamos para a realidade concreta do capitalismo percebemos que o monopólio é a concorrência organizada dos capitalistas na fase monopolista deste modo de produção. A rigor trata-se da concorrência levada às suas últimas consequências:

Há meio século, quando Marx escreveu $O$ capital, a livreconcorrência era, para a maior parte dos economistas, uma "lei natural”. A ciência oficial procurou aniquilar, por meio da conspiração do silêncio, a obra de Marx, que tinha demonstrado, com uma análise teórica e histórica do capitalismo, que a livre-concorrência gera a concentração da produção, e que a referida concentração, num certo grau do seu desenvolvimento, conduz ao monopólio. Agora o monopólio é um fato. (...) Os fatos demonstram que as diferenças entre os diversos países capitalistas, por exemplo no que se refere ao protecionismo ou ao livre câmbio, trazem consigo apenas diferenças não essenciais quanto à forma dos monopólios ou ao momento do seu aparecimento, mas que o aparecimento do monopólio devido à concentração da produção é uma lei geral e fundamental da presente fase de desenvolvimento do capitalismo. (LENINE, 1979, p. 590)

O movimento da própria sociedade capitalista gerou esta fase particular - o capitalismo monopolista -, na qual a síntese da livreconcorrência se transformou na agressiva concorrência entre os monopólios. E é neste contexto que os bancos assumem o seu novo papel e geram a concentração bancária, realizando a ingerência do capital financeiro no setor real da economia: a produção industrial:

A operação fundamental e inicial que os bancos realizam é a de intermediários nos pagamentos. É assim que eles convertem o capital-dinheiro inativo em capital ativo, isto é, capital que 
rende lucro; reúnem toda a espécie de rendimentos em dinheiro e colocam-nos à disposição da classe capitalista. À medida que vão aumentando as operações bancárias e se concentram num número reduzido de estabelecimentos, os bancos convertem-se, de modestos intermediários que eram antes, em monopolistas onipotentes, que dispõem de quase todo o capital-dinheiro do conjunto dos capitalistas e pequenos patrões, bem como da maior parte dos meios de produção e das fontes de matériasprimas de um ou de muitos países. Esta transformação dos numerosos modestos intermediários num punhado de monopolistas constitui um dos processos fundamentais da transformação do capitalismo em imperialismo capitalista. (LENINE 1979, p. 597)

Adicionado a estas características de concentração da produção com consequente concentração da riqueza e socialização da miséria, negação da livre-concorrência elevada à concorrência monopolista, novo papel dos bancos, ciclos de prosperidade e depressão está o caráter de transição desta fase superior. Chegamos ao calcanhar de Aquiles da reação gudiniana dos que se posicionam a favor do reconhecimento do capitalismo monopolista como fase histórica deste sistema. Gudin, como guardião do sistema, tem de protegê-lo da transitoriedade e garantir-lhe vida eterna. Portanto, restringe sua análise do monopólio como antítese da livre-concorrência e jamais como síntese histórica e antecâmera de uma nova formação social.

\section{Considerações finais}

Capitalismo naturalista é um dos conceitos centrais na obra de Eugênio Gudin e que ressalta o funcionamento da economia natural de mercado do século XIX e prepara o novo liberalismo do século XX. O atraso da realidade brasileira cria a necessidade de um pensador conservador como Eugênio Gudin; e o seu maior valor para os defensores do neoliberalismo é ter respondido a este papel com uma produção sem precedentes na história do pensamento econômico brasileiro. Neste sentido, foi um dos principais ideólogos do século na história passado. Lúcido do seu papel, não mediu esforços para concretizá-lo.

Estudar o pensamento gudiniano faz-se necessário em função da função que cumpriu e cumpre a sua obra. A força de suas ideias vem do poder da reação dos setores que temem rediscutir o lugar do Brasil no mundo dominado pela lógica do capital financeiro. Relembrar Gudin, reiterando os princípios que sempre defendeu, é lutar para perpetuar e aprofundar a atual subsunção da economia brasileira no mercado internacional. A defesa do neoliberalismo converge para a defesa da 
permanência da inserção mundial do capitalismo brasileiro nos moldes atuais, dependente dos centros hegemônicos do capitalismo monopolista.

Neoliberalismo: conceito negado pelos setores que explicitamente se identificam com a lógica do trabalho, incômodo para alguns, que optam pelo conforto do discurso moderado, e endeusado por outros que, como Gudin, tomam-no como bandeira de luta na defesa do sistema natural de produção: a economia de mercado. $\mathrm{O}$ economista carioca é muito mais aludido do que conhecido, aumentando-se com isso a necessidade do seu desvelamento. É evocado como o símbolo do neoliberalismo brasileiro, mas, curiosamente, é pouco estudado em função do alarde que o seu nome produz; portanto, ainda não decifrado para a grande maioria, fica muitas vezes somente uma referência vazia à sua obra. Que todos saibam o que realmente ele defendeu. E que Gudin seja evocado ou criticado em função do que produziu e não do que se possa dizer a seu respeito.

\section{Referências bibliográficas}

BIELSCHOWSKI, R. O pensamento econômico brasileiro: o ciclo ideológico do desenvolvimentismo. 2. ed. Rio de Janeiro: Contraponto, 1995.

BOCCHI, J. I. Processo de substituição de importações: da crise de 1930 ao II Plano Nacional de Desenvolvimento. In: MARQUES, R. M.; REGO, J. M. Economia brasileira. 6. e. São Paulo: Saraiva, 2018.

BORGES, Maria Angélica. Eugênio Gudin: capitalismo e neoliberalismo. São Paulo: Bienal/Educ/Fapesp, 1996.

GUDIN, Eugênio. Capitalismo e sua evolução. Rio de Janeiro: Almanak Laemmert, 1936.

. Aspecto econômico do corporatismo brasileiro. Rio de Janeiro:

Almanak Laemmert, 1938.

Para um mundo melhor. Ensaios sobre problemas de apósguerra. Rio de Janeiro: Civilização Brasileira, 1943.

LENINE, Vladimir I. Obras escolhidas t. 1. São Paulo: Alfa-Ômega, 1979.

MANTEGA, G. A economia política brasileira. São Paulo: Polis, 1984.

MARX, Karl. Miséria da filosofia. São Paulo: Grijalbo, 1977.

. O capital. São Paulo: Abril Cultural, 1983. 5. 3v.

SILVER, Beverly J. Forças do trabalho: movimentos trabalhistas e globalização desde 1870. São Paulo: Boitempo, 2005.

Como citar:

BORGES, Maria Angélica; BOCCHI, João Ildebrando. Capitalismo naturalista e modo de produção capitalista: crítica ao pensamento de 
Eugênio Gudin. Verinotio - Revista on-line de Filosofia e Ciências Humanas, Rio das Ostras, v. 25, n. 2, pp. 191-214, nov. 2019.

Data do envio: 21 jun. 2019

Data do aceite: 25 out. 2019 